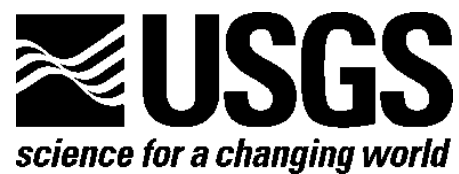

\title{
Geographic Information System (GIS) Representation of Coal-Bearing Areas in India and Bangladesh
}

Compiled by Michael H. Trippi and Susan J. Tewalt

Open-File Report 2011-1296

U.S. Department of the Interior

U.S. Geological Survey 


\section{U.S. Department of the Interior \\ KEN SALAZAR, Secretary}

\section{U.S. Geological Survey \\ Marcia K. McNutt, Director}

U.S. Geological Survey, Reston, Virginia 2011

For product and ordering information:

World Wide Web: http://www.usgs.gov/pubprod

Telephone: 1-888-ASK-USGS

For more information on the USGS-the Federal source for science about the Earth,

its natural and living resources, natural hazards, and the environment:

World Wide Web: http://www.usgs.gov

Telephone: 1-888-ASK-USGS

Suggested citation:

Trippi, M.H., and Tewalt, S.J., comps., 2011, Geographic information system (GIS) representation of coal-bearing areas in India and Bangladesh: U.S. Geological Survey Open-File Report 2011-1296, 27 p., available only at http:// pubs.usgs.gov/of/2011/1296.

Any use of trade, product, or firm names is for descriptive purposes only and does not imply endorsement by the U.S. Government.

Although this report is in the public domain, permission must be secured from the individual copyright owners to reproduce any copyrighted material contained within this report. 


\section{Contents}

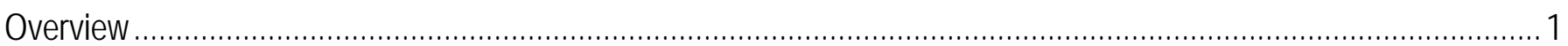

India .

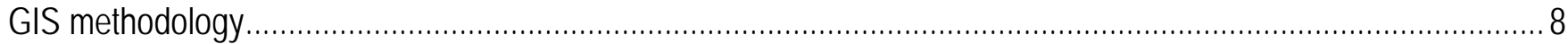

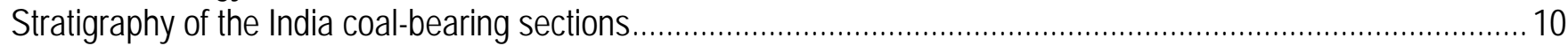

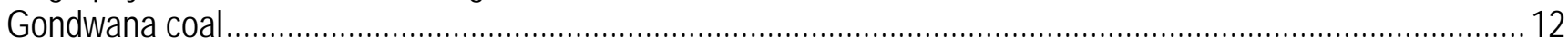

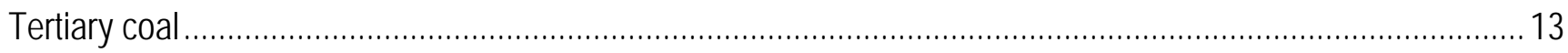

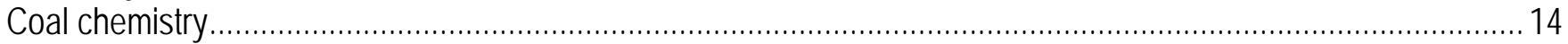

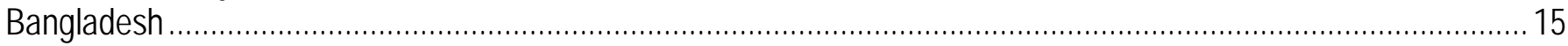

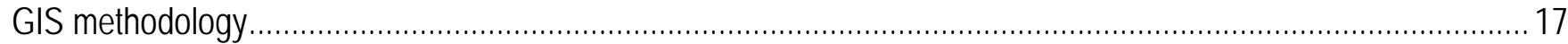

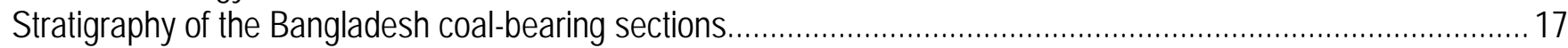

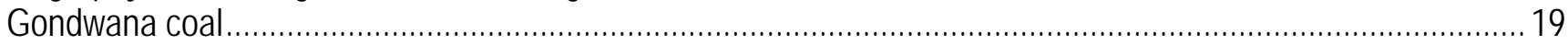

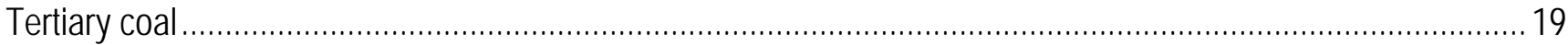

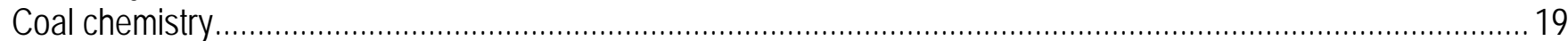

Acknowledgments

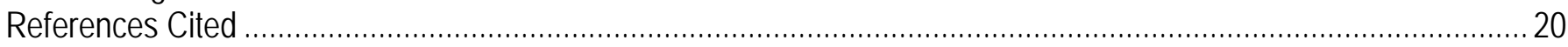

\section{Figures}

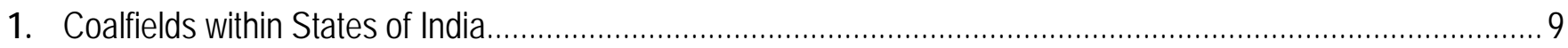

2. Correlation chart of stratigraphic units of the coalfields of India, indicating formation and group names............11

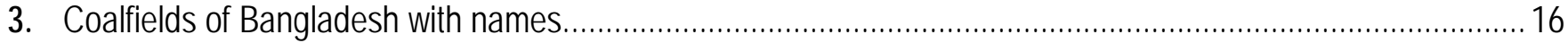

4. Correlation chart of stratigraphic units in the coalfields of Bangladesh, indicating formation

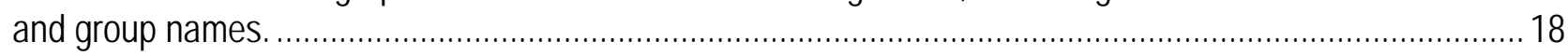

\section{Tables}

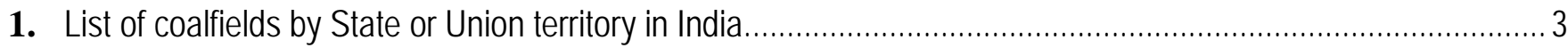

2. List of coalfields by district (previous to changes of names on January 25,2010 ) in Bangladesh...................... 17 


\section{Conversion Factors}

Inch/Pound to SI

\begin{tabular}{lll}
\hline \multicolumn{1}{c}{ Multiply } & \multicolumn{1}{c}{ By } & \multicolumn{1}{c}{ To obtain } \\
\hline foot $(\mathrm{ft})$ & \multicolumn{1}{c}{ Length } & \\
mile (mi) & 0.3048 & meter $(\mathrm{m})$ \\
yard (yd) & 1.609 & kilometer $(\mathrm{km})$ \\
\hline & 0.9144 & meter $(\mathrm{m})$ \\
\hline acre & Area & \\
square mile $\left(\mathrm{mi}^{2}\right)$ & 0.004047 & square kilometer $\left(\mathrm{km}^{2}\right)$ \\
& 2.590 & square kilometer $\left(\mathrm{km}^{2}\right)$ \\
\hline tonne $(\mathrm{t})(2205 \mathrm{lb})$ & Mass & \\
tonne $(\mathrm{t})(2205 \mathrm{lb})$ & 1 & Megagram $(\mathrm{Mg})$ \\
ton, short $(2,000 \mathrm{lb})$ & .028316 & Meters cubed $\left(\mathrm{m}^{3}\right)$ \\
ton, long $(2,240 \mathrm{lb})$ & 0.9072 & megagram $(\mathrm{Mg})$ \\
\hline
\end{tabular}

Temperature in degrees Celsius $\left({ }^{\circ} \mathrm{C}\right)$ may be converted to degrees Fahrenheit $\left({ }^{\circ} \mathrm{F}\right)$ as follows: ${ }^{\circ} \mathrm{F}=\left(1.8 \times{ }^{\circ} \mathrm{C}\right)+32$

Temperature in degrees Fahrenheit $\left({ }^{\circ} \mathrm{F}\right)$ may be converted to degrees Celsius $\left({ }^{\circ} \mathrm{C}\right)$ as follows:

${ }^{\circ} \mathrm{C}=\left({ }^{\circ} \mathrm{F}-32\right) / 1.8$ 


\title{
Geographic Information System (GIS) Representation of the Coal-Bearing Areas of India and Bangladesh
}

\author{
Compiled by Michael H. Trippi and Susan J. Tewalt
}

\section{Overview}

Per capita energy consumption rates in India and Bangladesh are among the lowest in the world (Ghosh, 2009; Mondal and others, 2010). Colloquially referred to as “energy poverty” (World Energy Council, 2010), the shortage of electric generating capacity necessitates that India and Bangladesh continue to use indigenous coal resources, despite significant global environmental issues related to coal consumption. The total installed electricity capacity of India as of July 31, 2008, was 145,587.97 megawatts (MW), based on power generation from 53 percent coal, 25 percent hydro-power, 10 percent natural gas, 8 percent renewable energy sources, and 3 percent nuclear sources (Ghosh, 2009). In Bangladesh, only 42 percent of the population in 2006 had access to electricity (Mondal and others, 2010). The Bangladesh Power Development Board (2011) indicates that Bangladesh has a total installed electric generation capacity of 6,760 MW; natural gas is the predominant energy source for electricity. Traditional biomass, including wood, agricultural waste, and dung, are the predominant energy sources in rural Bangladesh. The current supply of electricity in Bangladesh is unreliable, due to natural gas availability, power plant inefficiencies, high grid system losses, and electricity theft.

Geographic information system (GIS) information may facilitate energy studies, which in turn provide input for energy policy decisions. Prior to this study, no GIS file representing the occurrence of coal-bearing units in India or Bangladesh was known to exist. This is what prompted the creation of the GIS datasets in this report. The prior U.S. Geological Survey (USGS) methodology of using existing GIS surficial geologic shapefiles to select coal-bearing units and use them as a proxy for coalfields (Tewalt and others, 2008; Merrill and Tewalt, 2008) was not applicable in India and Bangladesh, where the mapped surface geology consists largely of alluvial cover or Precambrian rocks (Hearn and others, 2001). The shapefiles were generally built by scanning published maps or figures that depict the graphical extent of coalfields and then digitizing polygonal areas from the scanned files. Accompanying metadata contain lists of all map sources. A limited number of chemical and petrographic analyses of India and Bangladesh coal samples are included in the GIS point shapefiles. This report provides supporting information regarding the coal-bearing stratigraphic units for the coalfield GIS shapefiles.

This report is not intended to be an authoritative or comprehensive study of the Permian and Tertiary coals that are available for mining and combustion in India and Bangladesh. Publications of the Geological Survey of India and the Geological Survey of Bangladesh, as well as many recent research journal articles, are available for more detailed information. Lists of the India and Bangladesh coalfields are provided in tables 1 and 2, respectively. Brief descriptions of the coal-bearing geologic units follow.

\section{India}

According to the India Ministry of Home Affairs (2011), the 2001 census counted a population of approximately 1 billion people in India. Coal is the predominant indigenous energy resource 
available for use to meet the electrical needs within the republic and will continue to be used into the future. Most coal resources are bituminous in rank and Permian (Gondwana) in age; however, Tertiary coals and lignites are also present. Coalfields cover an area of about 34.7 thousand square kilometers $\left(\mathrm{km}^{2}\right)$ of a total land surface of 3.29 million $\mathrm{km}^{2}$ in India (Central Fuel Research Institute, 1993) and are shown in figure 1. Peninsular India contains the majority of population and coal resources, but demand for electricity in more remote areas (for example, western India) makes the location of local coal extremely important. The coalfields of India are listed in table 1 by State or Union territory and geologic age. In the myriad number of published reports, there are often multiple names or groupings for coalfields and several variations of their spelling. In addition, minor adjustments in geologic age, particularly of the Tertiary coals, are reported in more recent articles (for example Rage and others, 2003; Singh and others, 2010). The nomenclature for basin and coalfield names used in this report relies heavily on publications of the Geological Survey of India (1981, 1982, 1983, 1987, 2003) and Sastry and others (1977) for geologic names. 
Table 1. List of coalfields by State or Union territory in India.

[*, fields are not in GIS shapefile]

\begin{tabular}{|c|c|c|c|}
\hline State or Union territory & Group of fields or basin & Coalfield/lignite occurrence name or area (subarea) & Geologic age \\
\hline Andhra Pradesh ${ }^{2}$ & $\begin{array}{l}\text { Pranhita-Godavari Valley } \\
\text { Palar Basin }\end{array}$ & $\begin{array}{l}\text { Chinnur area, Manuguru area, Ramagundam-Mantheni area, } \\
\text { Indaram-Jaipuram area } \\
\text { Wardha Valley } \\
\text { Eluru-Rajamundri }\end{array}$ & $\begin{array}{l}\text { Permian } \\
\qquad, " \\
\text { Tertiary (Eocene) } \\
\text { Tertiary (Miocene-Pliocene) }\end{array}$ \\
\hline Arunachal Pradesh $^{1}$ & & $\begin{array}{l}\text { Namchik-Namphuk } \\
\text { Makum } \\
{\text { Unnamed fields }{ }^{1} / \text { Abor Hills, Aka Hills, Miri Hills, Daphala }}^{\text {Hills }^{8}} \\
\text { Miaobum }^{9} *\end{array}$ & $\begin{array}{l}\text { Tertiary (Oligocene-Miocene) } \\
\quad " \\
\text { " } \\
\text { " }\end{array}$ \\
\hline Assam $^{1}$ & & $\begin{array}{l}\text { Mikir Hills (Koilajan }{ }^{9} * \text {, Selvetta }{ }^{9}, \text { Khunbaman }^{9} * \text { ) } \\
\text { Makum } \\
\text { Dilli-Jaipore } \\
\text { North Cachar Hills }^{9} * \text { (Lengloi, Deigrung) } \\
\text { Diphu }{ }^{9} *\end{array}$ & $\begin{array}{l}\text { Tertiary } \\
\text { Tertiary (Oligocene-Miocene) } \\
\quad " \\
\quad " \\
\quad "\end{array}$ \\
\hline Chhattisgarh $^{3}$ & $\begin{array}{l}\text { Lakhanpur Group } \\
\text { Lakhanpur Group }\end{array}$ & $\begin{array}{l}\text { Lakhanpur } \\
\text { Sendurgarh, Damhamunda, Panchbhaini } \\
\text { Chirimiri } \\
\text { Hasdo-Arand } \\
\text { Korba } \\
\text { Mand-Raigarh } \\
\text { Bisrampur } \\
\text { Sonhat } \\
\text { Jhilimili } \\
\text { Tatapani-Ramkola }\end{array}$ & $\begin{array}{l}\text { Permian } \\
\text { " } \\
\text { " } \\
\text { " } \\
\text { " } \\
\text { " } \\
\text { " } \\
\text { " } \\
\text { " } \\
\text { " }\end{array}$ \\
\hline
\end{tabular}


Table 1. List of coalfields by State or Union territory in India.-Continued

[*, fields are not in GIS shapefile]

\begin{tabular}{|c|c|c|c|}
\hline State or Union territory & Group of fields or basin & Coalfield/lignite occurrence name or area (subarea) & Geologic age \\
\hline Jammu and $\mathrm{Kashmir}^{3,6}$ & & $\begin{array}{l}\text { Kalakot, Metka, Mahogala } \\
\text { Chakkar } \\
\text { Jangalgali } \\
\text { Chinkah } \\
\text { Lodhra } \\
\text { Ladda } \\
\text { Firozpur Shaliganga } \\
\text { Nichahom Baramula } \\
\text { Nagbal } \\
\text { Unnamed field (Dhansal-Sawalkot9 }\end{array}$ & $\begin{array}{l}\text { Tertiary } \\
\text { " } \\
\text { " } \\
\text { " } \\
\text { " } \\
\text { " } \\
\text { " } \\
\text { " }\end{array}$ \\
\hline Jharkhand $^{4}$ & $\begin{array}{l}\text { Damodar Valley } \\
\text { Damodar Valley } \\
\text { Damodar Valley } \\
\text { Rajmahal Group }\end{array}$ & $\begin{array}{l}\text { Ramgarh } \\
\text { West Bokaro } \\
\text { East Bokaro } \\
\text { Chope } \\
\text { North Karanpura } \\
\text { South Karanpura } \\
\text { Giridh } \\
\text { Deoghar (Saharjuri, Jainti, Kundit-Kuraiah) }^{\text {Jharia }}{ }^{8} \\
\text { Mahuagarhi, Brahmani, Pachwara, Chuperbhita, Hura } \\
\text { Raniganj }\end{array}$ & $\begin{array}{l}\text { Permian } \\
\text { " } \\
\text { " } \\
\text { " } \\
\text { " } \\
\text { " } \\
\text { " } \\
\text { " } \\
\text { " } \\
\text { " }\end{array}$ \\
\hline
\end{tabular}


Table 1. List of coalfields by State or Union territory in India.-Continued

[*, fields are not in GIS shapefile]

\begin{tabular}{|c|c|c|c|}
\hline State or Union territory & Group of fields or basin & Coalfield/lignite occurrence name or area (subarea) & Geologic age \\
\hline Jharkhand ${ }^{4}$ — continued & & $\begin{array}{l}\text { Auranga } \\
\text { Hutar } \\
\text { Daltonganj } \\
\text { Itkhori }\end{array}$ & $\begin{array}{l}\text { Permian } \\
\quad " \\
" \\
"\end{array}$ \\
\hline Kerala $^{6}$ & & $\begin{array}{l}\text { Nileswaram } \\
\text { Madayi } \\
\text { Warkala }\end{array}$ & $\begin{array}{l}\text { Tertiary (Miocene-Pliocene) } \\
\text { " } \\
\prime \prime\end{array}$ \\
\hline Madhya Pradesh ${ }^{3}$ & $\begin{array}{l}\text { Satpura Basin } \\
\text { Satpura Basin } \\
\text { Satpura Basin }\end{array}$ & $\begin{array}{l}\text { Tawa Valley (Sonada, Gurgunda, Shahpur, Dulhara, } \\
\text { Pathakhera) } \\
\text { Kanhan-Pench Valley } \\
\text { Mohpani } \\
\text { Umaria-Korar } \\
\text { Johilla } \\
\text { Sohagpur (Jhagrakhand-Bijuri, Kotma, Burhar-Amlai) } \\
\text { Singrauli }\end{array}$ & $\begin{array}{l}\text { Permian } \\
\text { " } \\
\text { " } \\
\text { " } \\
\text { " } \\
\text { " } \\
\text { " } \\
\text { " }\end{array}$ \\
\hline Maharashtra $^{2}$ & & $\begin{array}{l}\text { Wardha Valley } \\
\text { Bandar } \\
\text { Umrer } \\
\text { Kamptee } \\
\text { Ratnagiri }\end{array}$ & $\begin{array}{l}\text { Permian } \\
\prime \prime \\
\prime \prime \\
\prime \prime \\
\text { Tertiary }\end{array}$ \\
\hline Meghalaya $^{1}$ & $\begin{array}{l}\text { Garo Hills } \\
\text { Garo Hills } \\
\text { Garo Hills } \\
\text { Garo Hills } \\
\text { East Khasi Hills } \\
\text { East Khasi Hills }\end{array}$ & $\begin{array}{l}\text { Singrimari } \\
\text { Rongrenggiri } \\
\text { West Daranggiri } \\
\text { Siju } \\
\text { Balphakram-Pendengru, Holwang, Nabru, Zigrik } \\
\text { Langrin } \\
\text { Mawlong-Shella } \\
\text { Cherrapunji Plateau-Mawsynram- Laitryngew } \\
\text { Lyngkyrdem-Pynursla-Thangkinath* } \\
\text { Bapung } \\
\text { Um Rileng }\end{array}$ & $\begin{array}{l}\text { Permian } \\
\text { Tertiary (Eocene) } \\
\text { " } \\
\text { " } \\
\text { " } \\
\text { " } \\
\text { " } \\
\text { " } \\
\text { " } \\
\text { " } \\
\text { " }\end{array}$ \\
\hline
\end{tabular}


Table 1. List of coalfields by State or Union territory in India.-Continued

[*, fields are not in GIS shapefile]

\begin{tabular}{|c|c|c|c|}
\hline State or Union territory & Group of fields or basin & Coalfield/lignite occurrence name or area (subarea) & Geologic age \\
\hline Orissa $^{2}$ & & $\begin{array}{l}\text { Ib River } \\
\text { Talchir }\end{array}$ & $\begin{array}{c}\text { Permian } \\
\prime\end{array}$ \\
\hline Rajasthan $^{6}$ & Barmer basin & $\begin{array}{l}\text { Kapurdi } \\
\text { Khari } \\
\text { Gangashahr } \\
\text { Sarup Desar } \\
\text { Mudh } \\
\text { Kolayat } \\
\text { Gura } \\
\text { Bithnok } \\
\text { Palana } \\
\text { Chaneri } \\
\text { Bar Singhsar } \\
\text { Lalmdesar } \\
\text { Mandal Charnan } \\
\text { Raneri } \\
\text { Hiraki Dhani } \\
\text { Kasnau } \\
\text { Kurchera } \\
\text { Nimbri } \\
\text { Marwar Chapri } \\
\text { Butati } \\
\text { Merta Road } \\
\text { Hansiyas } \\
\text { Gangarda } \\
\text { Lamba Jatan } \\
\text { Mokala } \\
\text { Indawar } \\
\text { Nagarda } \\
\text { Nimla }\end{array}$ & $\begin{array}{l}\text { Tertiary (Eocene) } \\
\text { " } \\
\text { " } \\
" \\
" \\
" \\
" \\
" \\
" \\
" \\
" \\
" \\
" \\
" \\
" \\
" \\
" \\
" \\
" \\
" \\
" \\
" \\
" \\
" \\
" \\
" \\
"\end{array}$ \\
\hline
\end{tabular}


Table 1. List of coalfields by State or Union territory in India.-Continued

[*, fields are not in GIS shapefile]

\begin{tabular}{|c|c|c|c|}
\hline State or Union territory & Group of fields or basin & Coalfield/lignite occurrence name or area (subarea) & Geologic age \\
\hline & & $\begin{array}{l}\text { Bharka } \\
\text { Botiya } \\
\text { Hamir Ji Ki Dhani } \\
\text { Jalipa }\end{array}$ & $\begin{array}{l}\text { Tertiary (Eocene) } \\
\quad " \\
\quad " \\
\text { " }\end{array}$ \\
\hline Sikkim $^{7}$ & & Rangit Valley & Permian \\
\hline Tamil Nadu $^{2}$ & $\begin{array}{l}\text { Cauvery Basin } \\
\text { Palar Basin }\end{array}$ & $\begin{array}{l}\text { Neyveli (East and South areas) } \\
\text { Bahur } \\
\text { Bhubangiri } \\
\text { Srimushnam } \\
\text { Lalpettai } \\
\text { Jayamkonda Cholapuram } \\
\text { Mannargudi }\end{array}$ & $\begin{array}{l}\text { Tertiary (Eocene) } \\
\text { " } \\
\prime \prime \\
\prime \prime \\
\prime \\
\prime \prime \\
\text { " } \\
\text { Tertiary (Miocene-Pliocene) }\end{array}$ \\
\hline Uttar Pradesh $^{3}$ & & Singrauli & Permian \\
\hline West Bengal $^{5}$ & Damodar Valley & $\begin{array}{l}\text { Birbhum } \\
\text { Raniganj/Rakshitpur area } \\
\text { Darjeeling } \\
\text { Barjora }\end{array}$ & $\begin{array}{l}\text { Permian } \\
\prime \prime \\
\prime \prime\end{array}$ \\
\hline
\end{tabular}

${ }^{1}$ Geological Survey of India (1981).

${ }^{2}$ Geological Survey of India (1982).

${ }^{3}$ Geological Survey of India (1983).

${ }^{4}$ Geological Survey of India (1987).

${ }^{5}$ Geological Survey of India (2003).

${ }^{6}$ Geological Survey of India (2006).

${ }^{7}$ Ghosh (1997).

${ }^{8}$ Central Fuel Research Institute (1993).

${ }^{9}$ Atul K. Varma (written commun., 2011). 


\section{GIS methodology}

The Geological Survey of India (GSI) published Bulletin 45 (volumes I through V) between 1981 and 2003 to summarize the extensive geologic knowledge of Indian coal. The volumes (Geological Survey of India, 1981, 1982, 1983, 1987, 2003) include coalfield location maps, as well as information on coal quality and reserves, and served as the main source for the shapefiles. The plates showing the individual coalfields from each volume were scanned and georeferenced to (1) known latitude and longitude line intersections based on latitude and longitude "tick" marks from the original map or (2) to recognizable deviations in State and national boundary lines and shorelines. Base map projection information was unknown. The outlines of coal-bearing formations in the areas depicted on plates from Bulletin 45 were digitized and then attributed with field name and source references, but geologic formation names were not included. Some interpretative geologic contacts needed to be generated, as in the Wardha Valley of Andhra Pradesh and Maharashtra's Umrer and Kamptee coalfields, where interpretive boundaries of areas concealed by alluvium were estimated by USGS authors. Also, major igneous intrusions mapped on the plates of Bulletin 45 were designated as noncoal-bearing areas, because the intrusions generally sterilize the coal resource. Maps of detailed exploratory coal blocks within Gondwana coalfields are included in a publication (Geological Survey of India, 1977) that was not used as a source for the GIS shapefiles. Two coalfield outlines in this GIS dataset came from non-GSI publications (Ghosh, 1997). The locations of Tertiary lignite occurrences were based mostly on two maps presented by the Geological Survey of India (Geological Survey of India, 2006) at an underground coal gasification workshop sponsored by the U.S. Department of Energy, the India Ministry of Coal, and Coal India Ltd. Many of the Tertiary coal occurrences in western India are concealed by alluvium; thus locations may not be precise in the GIS dataset. The metadata file "IndiaCoalfields Metadata.htm” describes all GIS processing.

In general, all areas depicting coalfields or lignite occurrences may not be detailed enough in areal extent to use in the calculation of resources. Political boundaries (international and shorelines) used in figure 1 are from the U.S. Department of State (2011) and State boundaries are from Hijmans and others (2010). 


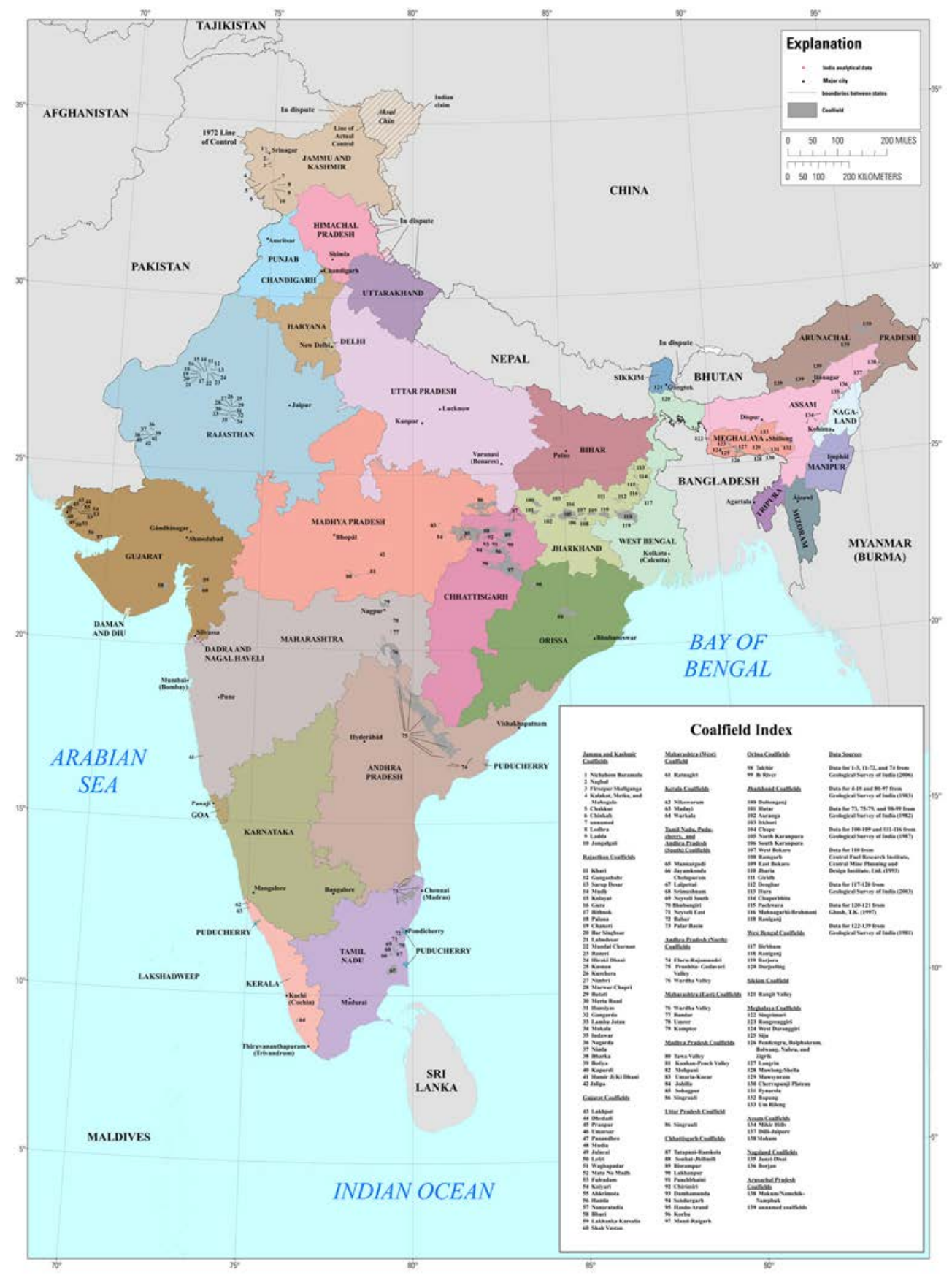

Figure 1. Coalfields within States of India.

Coal chemical and petrographic data for samples related to previous USGS studies in India are also included in a point shapefile (Tewalt and others, 2010). The accompanying metadata file is called "IndiaAnalyticalData Metadata.htm." Coal chemistry includes proximate and ultimate analyses from a commercial laboratory and major-, minor-, and trace-elements from a USGS laboratory. Additional coal quality information on Indian coals, dating back to the 1970s, is available in publications of the Central Institute of Mining and Fuel Research, formerly the Central Fuel Research Institute (Central Fuel Research Institute, 1979). 


\section{Stratigraphy of the India coal-bearing sections}

India has an extremely complex tectonic history and a stratigraphic succession that is commonly interrupted by unconformities and disconformities. Figure 2 is a highly generalized composite correlation chart (stratigraphic column) for the country, summarized from the text of Geological Survey of India’s Bulletin 45 volumes, with some augmentation by Gowrisankaran and others (1987). Figure 2 is idealized in the sense that all correlative units are listed; in actuality, the complete sequence shown does not exist in any one region. The text below includes brief descriptions of the Gondwana (Upper Carboniferous through Lower Cretaceous) and Tertiary coal-bearing units shown in figure 2, grouped by geologic age. The descriptions do not fully accommodate the variable nature of the stratigraphic sections over such a vast geographic extent and time period but are intended to serve as an introduction to the host rocks of Indian coals. A Cretaceous-age coalfield in Gujarat, called Ghuneri, is not included in this discussion or the GIS file because no base map was available. Mesozoic coals are not presently economically significant resources (SanFilipo and others, 1992). 


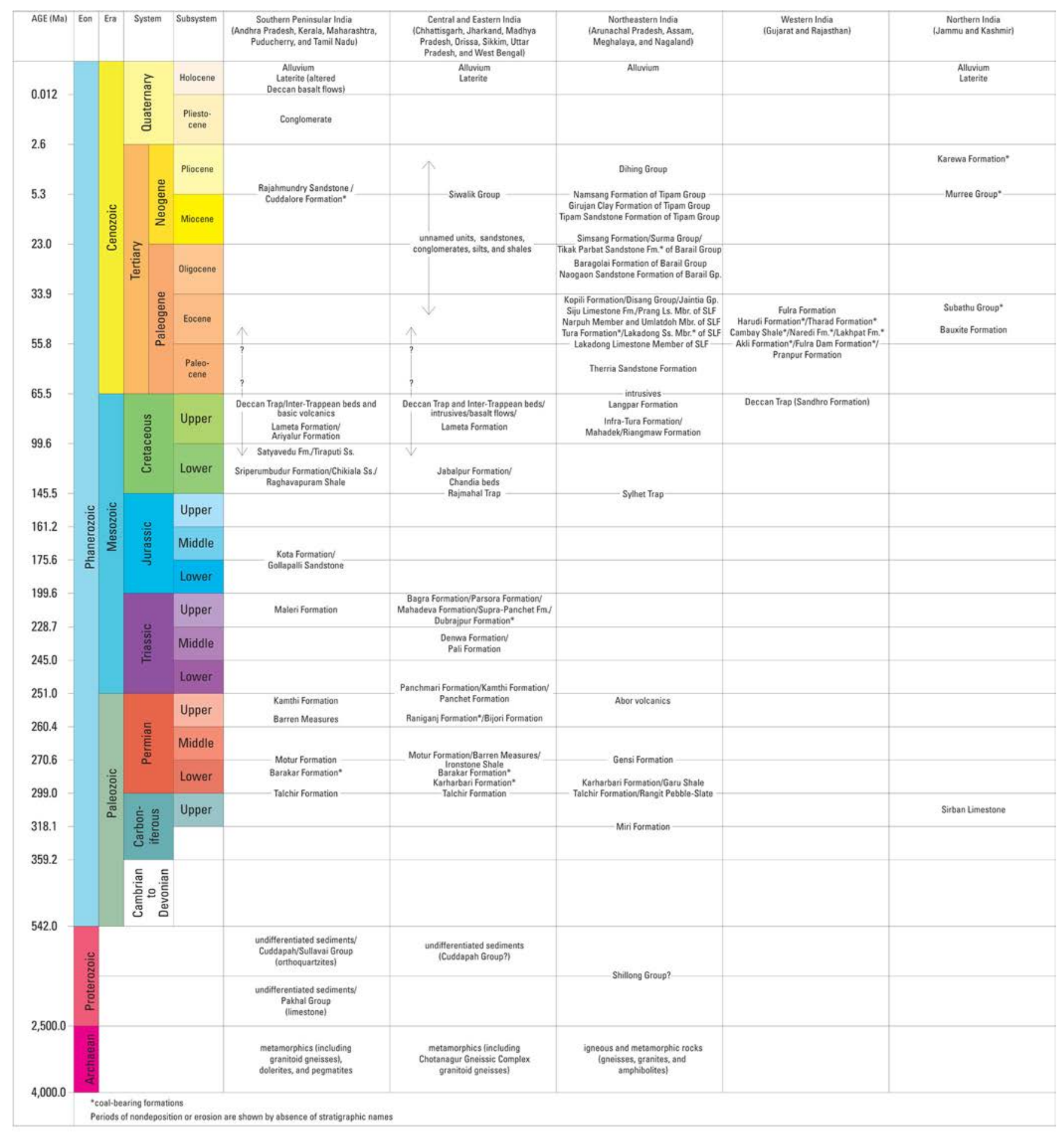

Abbreviations used: Fm. - Formation; Gp. - Group; Ls. - Limestone; Ma - Megaannum (millions of years); Mbr. - Member, SLF - Sylhet Limestone Formation; Ss. - Sandstone. Sources of stratigraphic data: Geological Survey of India (1981, 1982, 1983, 1987, 2003); Sastry (1977); Singh and Singh (1995).

Geological ages from USGS Fact Sheet 2010-3059; colors from International Commission on Stratigraphy (2009), except Tertiary from USGS Fact Sheet 2010-3059.

Figure 2. Correlation chart of stratigraphic units of the coalfields of India, indicating formation and group names. 


\section{Gondwana coal}

Gondwana units are thick wedges of clastic sediments deposited in elongated erosional intracratonic basins that widened over time (Pareek, 1988) and were deposited from Late Carboniferous to the beginning of the Cretaceous. Most coals are found in the lower Gondwana units, deposited during the Permian. Many formations are intruded by dolerites and lamprophyres, which locally affect the coal beds by increasing rank of the coal. There is controversy regarding the stratigraphic interpretation within some of the basins, where fragmentary fossil evidence used for identification conflicts with the accepted order of superposition (Dutta, 2001). Eastern Himalayan coals have been influenced by igneous activity and regional tectonic impacts and are thus often physically different from the peninsular India coals.

Upper Carboniferous to Lower Permian

Where sediments of this age exist, the Talchir Formation occurs in many coalfields. The Talchir Formation contains greenish sandstone and splintery (needle) shale, and unconformably overlies much older units — often Proterozoic gneisses or other rock types (Geological Survey of India, 1987). The Talchir Formation has a boulder bed (tillite) as the basal unit (Geological Survey of India, 1983), indicating a glacial origin. In small coalfields of Arunachal Pradesh north of the Brahmaputra River, the Miri Formation and possibly part of the Rangit Pebble-Slate of the Damuda Group represent this time period (Sastry and others, 1977).

Lower to Middle Permian

The Karharbari and Barakar Formations are assigned to the Lower Permian. The Karharbari Formation is generally composed of coarse sandstones and conglomerates (Geological Survey of India, 1987). It cannot be distinguished as a formation in all coalfields and is often considered a "stage" of the Barakar Formation (Fox, 1934; Sastry and others, 1977). Coals occur within this unit in the coalfields of the Damodar Valley and Rajmahal Group of Jharkhand (table 1). The Barakar Formation is a principal coal-bearing unit and is often divided into two or three members, with coals preferentially distributed among the members. The Barakar Formation coal beds are often thick and extensive. The formation achieves a maximum thickness of 1,000 meters (m) in the Sonhat coalfield of Chhattisgarh (Geological Survey of India, 1983) and 1,250 $\mathrm{m}$ in the Jharia coalfield of Jharkhand (Chandra, 1992). Many of the outcropping Barakar Formation coals in the East Bokaro coalfield of Jharkhand are burned (clinker), and burning has also altered other surficial rock exposures. In the eastern part of Jharkhand, the Jharia coalfield has present-day coal fires that cause subsidence of buildings and require relocation of the population.

Depending upon the coalfield, the Barakar Formation is cited as being either conformably or unconformably overlain by the "Barren Measures," which are a thick sequence of sandstone, sandy shale, and black shale. This interval, which is void of exploitable coal, is called the Motur Formation in the Satpura Basin coalfields (including the Tawa Valley, Kanhan Valley- Pench Valley, and Mohpani coalfields) in Madhya Pradesh, and in the Kamptee field in Maharashtra (Geological Survey of India, 1983); it is called the "Ironstone Shale" in the Raniganj coalfield of West Bengal (Sastry and others, 1977).

Upper Permian to Triassic

Informally, the stratigraphic sequence over the Barakar Formation is sometimes referred to as the "Supra-Barakar Formations.” In the Satpura Basin of Madhya Pradesh, the Bijori and Panchmari 
Formations overlie the Motur Formation (“Barren Measures”). Both formations are largely composed of sandstones and shales (Geological Survey of India, 1983). In Jharkhand, the Raniganj Formation overlies the Barren Measures and is largely composed of calcareous sandstones, with some carbonaceous shales. The Raniganj Formation also contains coal in the Singrauli coalfield of Madhya Pradesh, the West Bokaro and East Bokaro coalfields of Jharkhand, and the Raniganj coalfield in West Bengal (Geological Survey of India, 1987, 2003). The contact of the Raniganj Formation with the overlying Panchet Formation is often considered the boundary of the Permian and Triassic (Bandyopadhyay, 1996). In many areas, the Kamthi Formation (also called the Panchmari Formation) is present. Although the Kamthi Formation is largely composed of sandstones, in the Mand-Raigarh and Bisrampur coalfields of Chhattisgarh, some coals occur within the Kamthi Formation (Geological Survey of India, 1983).

Upper Triassic (Upper Gondwana)

Overlying the sandstones and shales of the Panchet Formation are coarse, often ferruginous sandstones lying within the Upper Triassic Mahadeva or Dubrajpur Formations of Jharkhand. In the Satpura Basin of Madhya Pradesh, the equivalent unit is called either the Bagra or the Parsora Formation (Geological Survey of India, 1983). In the Pranhita-Godavari Valley and Wardha Valley coalfields of Andhra Pradesh, the equivalent is called the Maleri Formation (Geological Survey of India, 1982). Most of these units do not contain coals, although the Dubrajpur Formation does have thin coal bands in the Birbhum coalfield of West Bengal (Geological Survey of India, 1987).

Tertiary coal

Tertiary sediments overlie the Deccan Traps, extensive volcanic tuffs and basalts, which were deposited from Late Cretaceous to Early Eocene (Krishnan, 1956). The Rajmahal volcanics in Jharkhand and West Bengal appear to be slightly older-Early Cretaceous in age (Geological Survey of India, 1987, 2003). The Tertiary coals of India constitute a minor portion of Indian coal reserves. Tertiary-age lignites are found in northwestern, western, and southern India and are believed to have formed at Indian plate margins (Singh and others, 2010). Some lignite fields have coals ranked as high as semi-anthracite, which is likely due to maturation caused by deep-seated intrusive bodies (Pareek, 1988). Most of the lignite occurrences in western India are covered by unconsolidated surficial materials, including alluvium and aeolian deposits (Hearn and others, 2001), and it is difficult to correlate their stratigraphic position.

Paleocene to lowermost Eocene

The Fulra Dam Formation, composed of gray argillite, sand, and lignite, bears coals in the Mata No Madh field (Kutch basin) of Gujarat and overlies the Deccan Traps (Sandhro Formation). Coals of this age also occur in the Palana lignite field of Rajasthan (Gowrisankaran and others, 1987).

\section{Lower to upper Eocene}

In Meghalaya, the Tura Formation, largely composed of sandstone, bears coals in the Garo Hills group of coalfields (table 1). This unit is equivalent to the Lakadong Sandstone Member of the Sylhet Limestone Formation (SLF) that occurs in other coalfields in Meghalaya (Geological Survey of India, 1981). The Siju Limestone and Kopili Formation of Meghalaya are devoid of coal. Equivalent units are in the Disang Group (gray, splintery shale) in Nagaland and parts of Assam. The coals of Mikir Hills in Assam occur within the Jaintia Group and Syhlet Limestone (Singh and others, 2010). 
In Jammu and Kashmir, coals occur in the Subathu Group, composed of limestones and shales that unconformably overlie a bauxite unit (Geological Survey of India, 1983). The Kalakot and Metka coal occurrences of Jammu and Kashmir have middle Eocene coals within the Subathu Group that have been altered to higher rank (semi-anthracite) from deep-seated igneous heating.

In Gujarat, the lower Eocene units include the lower Tharad Formation, the Cambay Shale, the Lakhpat Formation (Bandyopadhyay, 1996), and the Naredi Formation (Rage and others, 2003).

Equivalent units are called the Akli Formation in the Kapurdi lignite area of Rajasthan (Mukherjee and others, 1992). The coal-bearing middle Eocene unit in Gujarat is the Harudi Formation (greenish-gray shale and lignitic clays) in the Panandhro and Mata No Madh fields. The Panandhro lignites are in strata believed to be equivalent to the Laki Formation of Sindh, Pakistan (SanFilipo and others, 1992).

\section{Oligocene to Miocene}

The Barail Group crops out within Assam, Nagaland, and Arunachal Pradesh and contains sandstones and sandy shales. Within the Barail Group, the Tikak Parbat Formation contains coals, particularly in the Janzi-Disai and Borjan (Nazira) coalfields of Nagaland (Geological Survey of India, 1981). The same-age Simsang Formation in Meghalaya is largely silty shale and void of coal, as is the Surma Group, which is mostly sandstone and conglomerate in both the Meghalaya's Langrin coalfield and Assam’s Mikir Hills coalfield (Geological Survey of India, 1981).

\section{Miocene to Pliocene}

Lignites of Miocene to Pliocene age are found in the States of Kerala, Jammu, and Kashmir. The Karewa Formation (Pliocene) (Gowrisankaran and others, 1987) in Jammu and Kashmir contains lignites, as well as gray clay, sandy clay, sands, and conglomerates. Jammu and Kashmir coals also occur in the Muree Group (Miocene to Pliocene) (Singh and Singh, 1995), which overlies the Eocene Subathu Group. The Cuddalore Formation is coal bearing in the Palar Basin (Geological Survey of India, 1982) of Tamil Nadu.

\section{Coal chemistry}

Indian coals are generally moderate to high in ash yield—quite often around 30 percent on an asreceived basis. Ranges of ash yield and sulfur content can be found in Geological Survey of India publications (1977, 1981, 1982, 1983, 1987, 2003). In 2006, there were 37 coal beneficiation plants (washeries) in India; 20 are coking coal washeries and 17 are for non-coking coal (Arora and others, 2006). Coal of coking quality is not widespread but occurs in the Jharia and Raniganj coalfields of Jharkhand and in a few coalfields in Madhya Pradesh. Tertiary coals in northeastern India are higher in sulfur than the Gondwana coals. As an example, the Dilli-Jaipore coalfield of Assam has coals that average approximately 6 percent total sulfur (Geological Survey of India, 1981). The lignites of southern and western India are lower in rank and thus higher in moisture (Sharma and others, 2004). Permian-age coal samples in the analytical data GIS point shapefile (only from the Sohagpur coalfield of Madhya Pradesh) have a range for ash yield of 8.53 to 63.09 percent and a total sulfur range of 0.1 to 2.34 percent. The few Tertiary-age coal samples in Rajasthan show ash yields of 9.58 to 43.79 and sulfur from 3.31 to 13.89 on an as-received basis (Tewalt and others, 2010). Other data sources should be used to supplement the limited analytical and petrographic data presented here. 


\section{Bangladesh}

Bangladesh is approximately 140,000 $\mathrm{km}^{2}$ in area (BANBEIS, 2011) and is home to 160 million people as of 2008 (Fong-Sam and others, 2010). The major indigenous non-renewable resource in Bangladesh is natural gas (Islam and Hayashi, 2008), with an estimated 32.1 trillion cubic feet (TCF) of undiscovered, conventional, natural gas resources in the country (USGS-Bangladesh Gas Assessment Team, 2001; Persits and others, 1997). Traditional biomass, as well as natural gas and imported fuel, provides the majority of electricity. However, the government plans to generate 2,900 MW of power from coal in the next 5 years (Mondal and others, 2011). Bangladesh coals formed in the same time periods (Permian and Eocene) in which coal-bearing units in India formed but are much less extensive (fig. 3). Between 1962 and 1997, five Permian (Gondwana) coalfields were discovered in Bangladesh (table 2). Not all Gondwana basins have coal that can be easily produced; some coal occurs at depths that exceed current exploitation capability, such as the Jamalganj coalfield where depths to coal can exceed 1,000 m. From 2005 to 2009, Bangladesh coal production grew from 85,000 to 96,000 short tons (Energy Information Agency, 2011). Bangladesh also plans to diversify its electrical generation capacity through nuclear power and is investigating coalbed methane production and geothermal potential as well (Guha and others, 2010). The government published a renewable energy policy in 2008. 


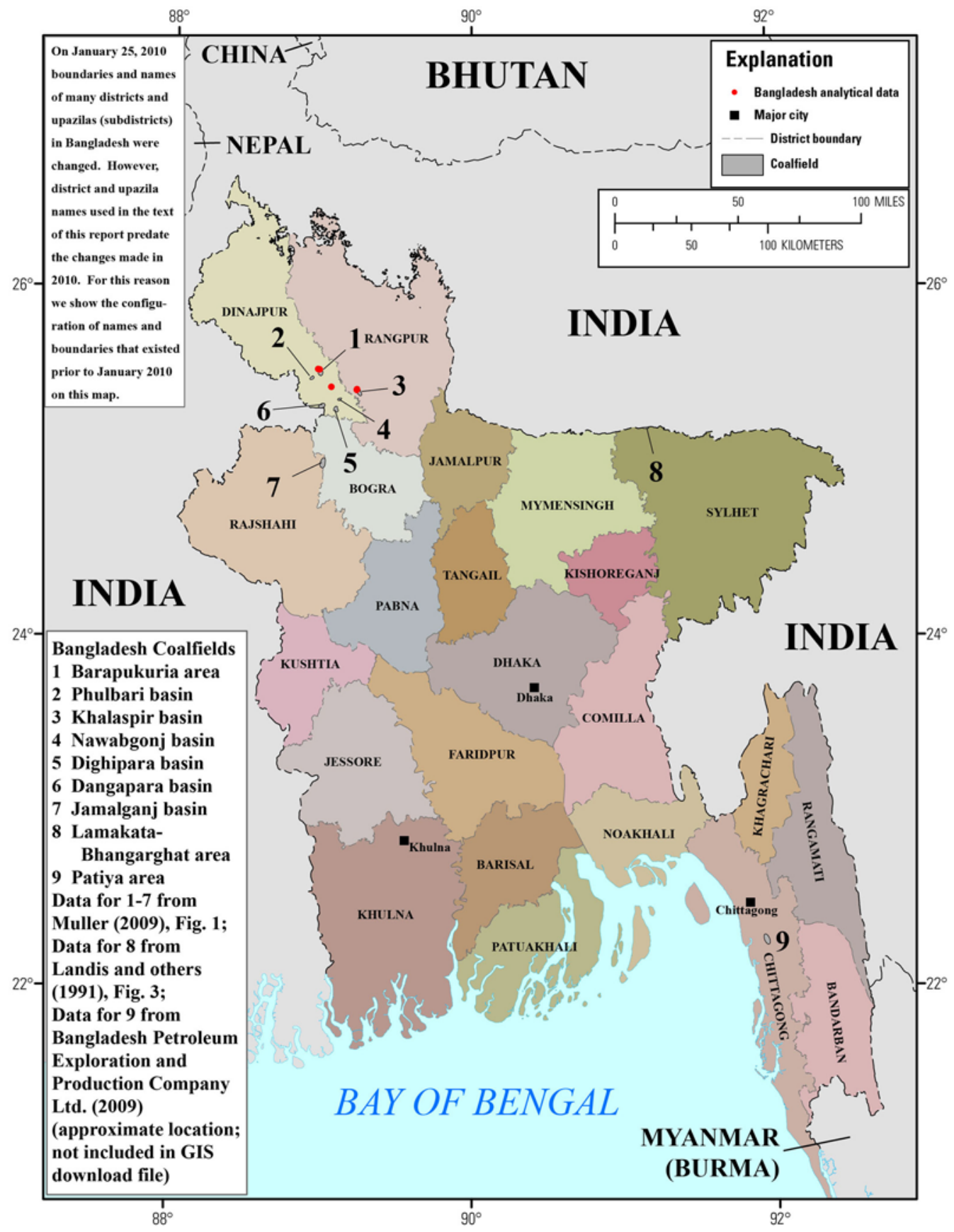

Figure 3. Coalfields of Bangladesh with names. 
Table 2. List of coalfields by district (previous to changes of names on January 25, 2010) in Bangladesh.

[*, fields are not in GIS shapefile]

\begin{tabular}{lll}
\hline $\begin{array}{l}\text { District and Upizila } \\
\text { (Subdistrict) }\end{array}$ & $\begin{array}{l}\text { Coalfield name or } \\
\text { area }\end{array}$ & Geologic age \\
\hline Dinajpur District & Barakupuria $^{2}$ & Permian \\
Dinajpur District & Phulbari $^{2}$ & Permian \\
Dinajpur District & Dighipara $^{2}$ & Permian \\
$\begin{array}{l}\text { Rangpur District } \\
\text { Jaipurhat Upazila of }\end{array}$ & Khalashpir $^{1}$ & Permian \\
$\begin{array}{l}\text { Bogra District } \\
\text { Dinajpur District }\end{array}$ & Nawabgonj $^{2}$ & Permian \\
Dinajpur District & Dangapara $^{3}$ & Permian \\
$\begin{array}{l}\text { Bandarban District } \\
\text { Sunamganj Upizila } \\
\text { of Sylhet District } \\
\text { Chittagong District }\end{array}$ & $\begin{array}{l}\text { Lamakata }^{1} \\
\text { Bhangarghat }^{1}\end{array}$ & Permian \\
Sylhet District & Patiya $^{4}$ & Eocene \\
\hline
\end{tabular}

${ }^{1}$ Landis and others (1991).

${ }^{2}$ Islam and Hayashi (2008).

${ }^{3}$ Muller (2009).

${ }^{4}$ Banglapedia (2006).

\section{GIS methodology}

Permian-age basins of Bangladesh are small in areal extent and have no surficial expression, being overlain by Tertiary and Quaternary deposits (Islam and Hayashi, 2008). Figures from research articles and administrative reports of the USGS were used to approximate the location of coalfields for the shapefile, with sources noted in the metadata file ("BangladeshCoalfields Metadata.htm"). Political boundaries (international and shorelines) used in figure 3 are from the U.S. Department of State (2011) and district and upazila boundaries are from Hijmans and others (2010). The point shapefile has only partial chemical analyses for three of the five drill holes presented, as well as limited sample depths in core GDH-40. Proximate and ultimate analyses are not available. Petrographic analyses are from Bostick and others (1991) and major-, minor-, and trace-element analyses are from a USGS laboratory. The coal chemistry metadata file for Bangladesh is called "BangladeshAnalyticalData Metadata.htm."

\section{Stratigraphy of the Bangladesh coal-bearing sections}

Figure 4 is a generalized stratigraphic column of Bangladesh (adapted from Khan and Muminullah, 1988). Formation names vary by area within the country but often are the same as in bordering areas of India. 


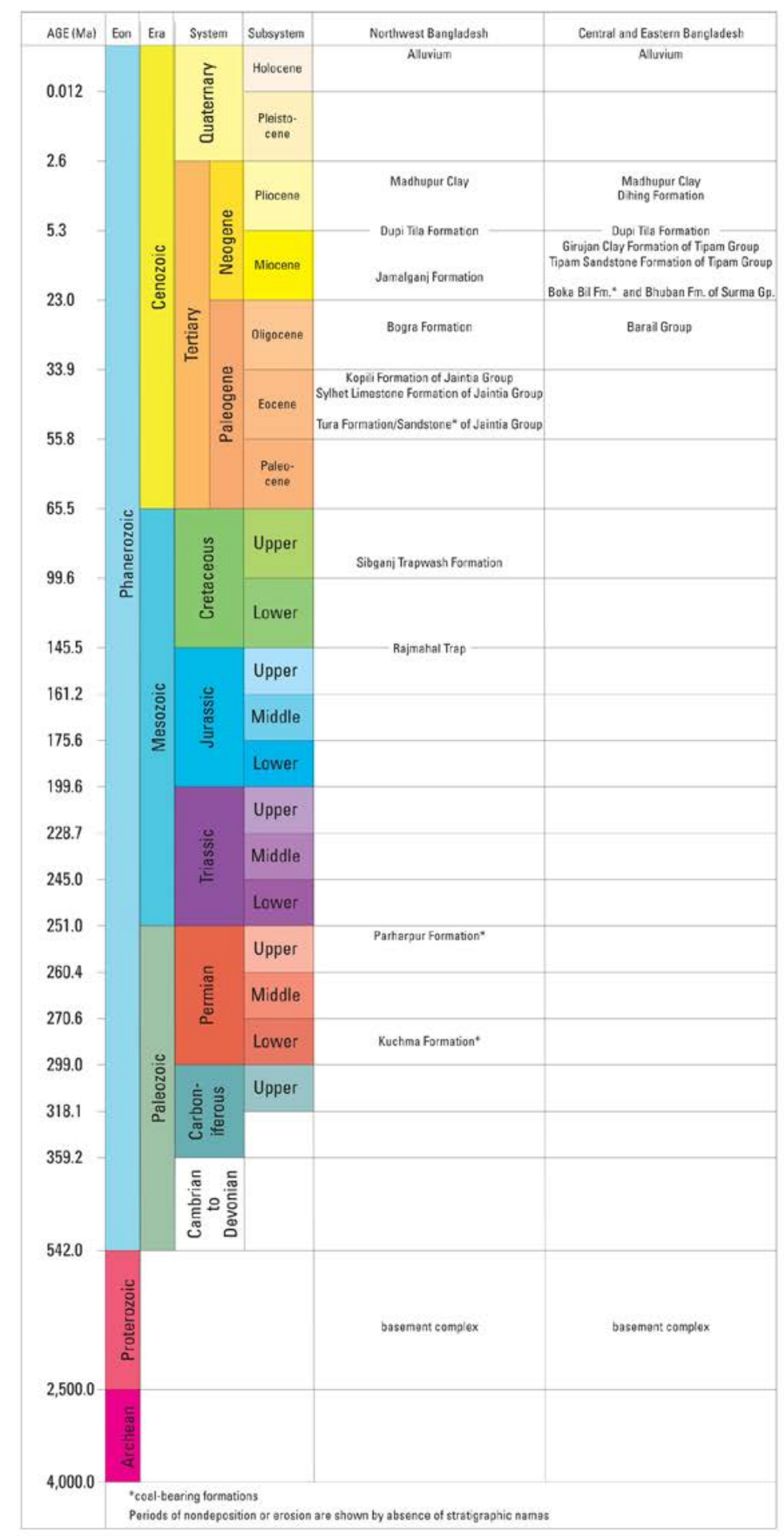

Abbreviations used: Fm. - Formation; Gp. - Group; Ma - Megaannums (millions of years).

Source of stratigraphic data: Khan and Muminullah (1988), Rahman and others (1985).

Geological ages from USGS Fact Sheet 2010-3059; colors from International Commission on Stratigraphy (2009),

except Tertiary from USGS Fact Sheet 2010-3059

Figure 4. Correlation chart of stratigraphic units in the coalfields of Bangladesh, indicating formation and group names. 


\section{Gondwana coal}

The Barapukuria coalfield in the Dinajpur district of northwestern Bangladesh (Bakr and others, 1996) is currently the only coal mine that has been developed in Bangladesh's Gondwana coals. Barapukuria is an underground longwall mine and has had operational problems mostly because of flooding from an overlying aquifer (Dupi Tila Formation). Environmental concerns have caused local resistance to further mining in Barapukuria and in adjacent Gondwana coalfields. The mine reported production of 109,098 tonnes of coal from 1 July 2008 to 30 June 2009 (Fong-Sam, 2011).

In northwestern Bangladesh, the Nawabgonj and Dangapara coalfields have unproven resources. Coal is considered too deep for exploitation near Bogra; four other Gondwana basins in northwestern Bangladesh with no known coal (to date) include Badargonj, Osmanpur, Burirdoba, and Shimnager (Muller, 2009).

The Early Permian-age Kuchma Formation contains coal (Khan and Muminullah, 1988). Overlying it, the Parharpur Formation hosts seven or more thick coal beds from 650 to 1,160 m deep in the Jamalganj coalfield of northwestern Bangladesh. Permian units in other coalfields have not been fully documented and are named simply "Gondwana Group.”

\section{Tertiary coal}

Early Tertiary coals in northeastern Bangladesh are similar to those that crop out in adjoining India. However, the coal areas appear to be much less extensive in Bangladesh, and beds may be steeply inclined and at depths not optimal for mining (Landis and others, 1991). The Lamakata and Bhangarghat areas, near the border with Meghalaya, India (fig. 3), have coals in the Tura Formation, which is early Eocene in age (Landis and others, 1991). The approximate location of the Patiya area of the Chittagong district (southeastern Bangladesh) is shown in figure 3, based on a news release of the Bangladesh Petroleum Exploration and Production Company Limited (2009), but there is nothing else published regarding the coal in this area. No mapped location of the Lubachhara area in the Sylhet district of northeastern Bangladesh was available (Banglapedia, 2006); therefore, it is not included in the GIS shapefile and is not shown in figure 3. In the Rangamati district of southeast Bangladesh, very minor coal resources of no economic importance are believed to occur in the Miocene Boka Bill Formation, which is largely composed of shale, siltstone, and sandstone (Rahman and others, 1985). It was not deemed significant enough to show in figure 3.

\section{Coal chemistry}

The quality of Permian coals is considered to be better in Bangladesh than in India-lower in ash yield and lower in sulfur. Coal produced at the Barakupuria mine averages about 12 percent ash yield and 0.53 percent sulfur (Petrobangla, 2011). The limited data in the point file for Bangladesh Permian coals from five holes indicate a range of 7.63 to 67.6 percent ash yield and 0.24 to 3.15 percent total sulfur (both as-received basis).

\section{Acknowledgments}

The thorough compilations of information on India coal in Bulletin 45 by the Geological Survey of India were indispensable to this effort, as was the interagency effort between the Coal Wing of the Geological Survey of India (Abhijit Mukhopadhyay and S.K. Mukhopadhyay) funded by the U.S. India Fund administered by the U.S. Department of State, which allowed the USGS analysis of some coal samples. Sohagpur basin coal petrographic analyses were provided by Peter D. Warwick. In Rajasthan, India, coal samples were collected by John R. SanFilipo with the assistance of K.D. Sharma, formerly of 
the Central Arid Zone (India) Development Authority, and the Rajasthan State Mineral Development Corporation; partial funding was provided by the U.S. Department of Agriculture. Petrographic analyses of the Rajasthan coals (Giral mine) were provided by James C. Hower and Cody D. Patrick at the University of Kentucky Center for Applied Energy Research in Lexington. Bangladesh cores were made available for analysis by the Geological Survey of Bangladesh (M. Nazrul Islam). Major-, minor-, and trace-element data were provided by the USGS Energy Geochemistry Laboratory and ultimate and proximate analyses by Commercial Testing of Somerset, Pa. Appreciation is also expressed to all earlier USGS researchers in India and Bangladesh: Edwin R. Landis (deceased), Peter D. Warwick, John R. SanFilipo, Robert M. Milici, Harold. J. Gluskoter, Neely H. Bostick, Craig J. Wandry, and William J. Betterton. We express appreciation for the instructive reviews by Alexander W. Karlsen, Harold J. Gluskoter, and Yolanda Fong-Sam of the U.S. Geological Survey, and also by Dr. Atul K. Varma of the Department of Geology, Indian School of Mines in Dhanbad, India.

\section{References Cited}

Arora, V., Jha, U., Bandhopadhyay, P., and Kumar, S., 2006, An investigation of the relationship between raw coal characteristics and effluent quality of Kedla and Rajrappa washeries; Jharkhand, India: Journal of Environmental Management, v. 78, p. 392-404.

Bakr, M.A., Rahman, Q.M.A., Islam, M.M., Islam, M.K., Uddin, M.N., Resan, S.A., Halder, M.J., Sultan-Ul-Islam, M., Ali, M.W., Chowdhury, Mokbul-E-Ala, Mannan, K.H., and Anam, A.N.M.H., 1996, Geology and coal deposit of Barapukuria Basin, Dinajpur district, Bangladesh: Geological Survey of Bangladesh, v. 8, part 1, 42 p. and annex.

Bandyopadhyay, R.K., 1996, A collection of papers on the lithostratigraphy and paleoenvironment of some coal and lignite basins in peninsular India: Geological Survey of India, Special Publication No. 20, 74 p.

Bangladesh Bureau of Educational Information and Statistics (BANBEIS), 2011, Country profile, 1 p., accessed April 5, 2011, at http://www.banbeis.gov.bd/bd_pro.htm.

Bangladesh Petroleum Exploration and Production Company Ltd. (BAPEX), 2009, Bangladesh Economic News, November 7, 2009: BAPEX Web site, accessed July 26, 2011, at http://www.bssnews.net/newsDetails.php?cat=8\&id=69137\&date=2009-11-06.

Bangladesh Power Development Board, 2011, Key statistics: Bangladesh Power Development Board Web site, accessed April 5, 2011, at http://www.bpdb.gov.bd/key_statistics.htm.

Banglapedia, 2006, Lignite: Banglapedia Web site, accessed May 4, 2011, at http://www.banglapedia.org/httpdocs/HT/L_0102.HTM.

Bostick, N.H., Betterton, W.J., Gluskoter, H.J., and Islam, M.N., 1991, Petrography of Permian "Gondwana" coals from boreholes in northwestern Bangladesh, based on semiautomated reflectance scanning: Organic Geochemistry, v. 17, no. 4, p. 399-413.

Chandra, D., 1992, Jharia coalfields: Bangalore, Geological Society of India, Mineral Resources of India, v. 5, 149 p.

Central Fuel Research Institute, Central Mine Planning and Design Institute, Ltd. (CFRI), 1993, Coal Atlas of India: Calcutta, India, Coal India Ltd., 129 p.

Central Fuel Research Institute, 1979, Indian coals quality evaluation data-Chirimiri, Sohagpur, Johilla River, Umaria, Pench-Kanhan-Tawa Valley, and Mohpani coalfields: Dhanbad, Bihar, Central Fuels Research Institute, v. 6, 221 p.

Dutta, Prodip, 2001, Gondwana lithostratigraphy of peninsular India: Gondwana Research, v. 5, no. 2, p. 540-553. 
Energy Information Administration, 2011, International Energy Statistics for coal: Energy Information Administration Web site, accessed March 12, 2011, at http://www.eia.doe.gov/cfapps/ipdbproject/iedindex3.cfm?tid=1\&pid=7\&aid=1\&cid=r7,\&syid=2005 \&eyid=2009\&unit=TST.

Fong-Sam, Yolanda, 2011, The mineral industry of Bangladesh: U.S. Geological Survey 2009 Minerals Yearbook-Bangladesh (advance release), 5 p., accessed July 25, 2011, at http://minerals.usgs.gov/minerals/pubs/country/2009/myb3-2009-bg.pdf.

Fong-Sam, Yolanda, Kuo, C.S., Shi, Lin, Tse, Pui-Kwan, Wacaster, Susan, and Wilburn, D.R., 2010, The mineral industries of Asia and the Pacific: U.S. Geological Survey 2008 Minerals Yearbook-Asia and the Pacific, 25 p., accessed July 25, 2011, at http://minerals.usgs.gov/minerals/pubs/country/2008/ myb3-sum-2008-asia-pacific.pdf.

Fox, C.S., 1934 (reprinted 2001), The Lower Gondwana coalfields of India: Calcutta, India, Memoirs of the Geological Survey of India, v. LIX, 368 p.

Geological Survey of India, 1977, Exploration in some major coalfields of India: New Delhi, India, Geological Survey of India Miscellaneous Publication No. 35, 584 p., 50 pls.

Geological Survey of India, 1981, Coalfields of northeastern India, in Raja Rao, C.S., ed., Coalfields of India, volume I: Calcutta, India, Geological Survey of India Bulletin Series A, no. 45, 76 p., 15 pls.

Geological Survey of India, 1982, Coal resources of Tamil Nadu, Andhra Pradesh, Orissa and Maharashtra, in Raja Rao, C.S., ed., Coalfields of India, volume II: Calcutta, India, Geological Survey of India Bulletin Series A, no. 45, 103 p., 13 pls.

Geological Survey of India, 1983, Coal resources of Madhya Pradesh, Jammu and Kashmir, in Raja Rao, C.S., ed., Coalfields of India, volume III: Calcutta, India, Bulletin Series A, no. 45, 204 p., 18 pls.

Geological Survey of India, 1987, Coal resources of Bihar (excluding Dhanbad district), in Raja Rao, C.S., ed., Coalfields of India, volume IV, Part 1: Calcutta, India, Bulletin Series A, no. 45, 336 p., 18 pls.

Geological Survey of India, 2003, Coal resources of West Bengal, in Raja Rao, C.S., ed., Coalfields of India, volume V: Calcutta, India, Bulletin Series A, no. 45, 109 p., 4 pls.

Geological Survey of India, 2006, Coal resource position in India; Presented at Underground Coal Gasification Workshop, November 12-15, 2006, Kolkata, India, accessed April 5, 2011, at http://www.fossil.energy.gov/international/Publications/ucg_1106_gsi.pdf.

Ghosh, S., 2009, Electricity supply, employment and real GDP in India-Evidence from cointegration and Granger-causality tests: Energy Policy, v. 37, p. 2926-2929.

Ghosh, T.K., 1997, Petrography and metamorphism of the lower Gondwana (Permian) coal of the Rangit Valley, eastern Himalayas, India: International Journal of Coal Geology, v. 33, p. 351-368.

Gowrisankaran, S., Sethi, P.P., Hariharan, R., and Agrawal, K.P., 1987, Lignite deposits of India-Their occurrences, depositional features, and characteristics: Proceedings of the National Seminar on Coal Resources of India, p. 481-553.

Guha, D.K., Henkel, Herbert, and Imam, Badrul, 2010, Geothermal potential in Bangladesh—Results from investigations of abandoned deep wells: Bali, Indonesia, Proceedings of the World Geothermal Congress, April 25-29, 2010, 8 p.

Hearn, P.P., Jr., Hare, T.M., Schruben, P., Sherrill, D., LaMar, C., and Tsushima, P., 2001, Global GIS database; Digital atlas of South Asia: U.S. Geological Survey Digital Data Series 62-C, CD-ROM.

Hijmans, R.J., Guarino, Luigi, Jarvis, Andy, O’Brien, Rachel, Mathur, Prem, Bussink, Coen, Cruz, Mariana, Barrantes, Israel, and Rojas, Edwin: DIVA-GIS, accessed December 2010, at http://www.diva-gis.org/. 
India Ministry of Home Affairs, 2011, Census of India 2001: India Ministry of Home Affairs Web site, accessed March 17, 2011, at http://www.censusindia.gov.in/2011-common/

CensusDataSummary.html.

International Commission on Stratigraphy, 2009, International stratigraphic chart: International Commission on Stratigraphy Web site, accessed April 1, 2011, at http://www.stratigraphy.org/upload/ISChart2009.pdf.

Islam, M.R., and Hayashi, Daigoro, 2008, Geology and coal bed methane resource potential of the Gondwana Barapukuria coal basin, Dinajpur, Bangladesh: International Journal of Coal Geology, v. 75, p. 127-143.

Khan, M.R., and Muminullah, M., 1988, Stratigraphic lexicon of Bangladesh: Records of the Geological Survey of Bangladesh, v. 5, pt. 1, 70 p.

Krishnan, M.S., 1956, Volcanic rocks of India: Bulletin of Volcanology, v. 18, p. 125-132.

Landis, E.R, Islam, M.N., Gluskoter, H.J., Bostic, Neely, Rahman, Q.M.A., and Abdullah, S.K.M., 1991, Contributions to coal geology of Bangladesh: U.S. Geological Survey Project Report, Bangladesh Investigation (IR)BG-9, 132 p.

Merrill, M.D., and Tewalt, S.J., 2008, GIS representation of coal-bearing areas in Africa: U.S. Geological Survey Open-File Report 2008-1258. (Also available at http://pubs.usgs.gov/of/2008/1258/.)

Mondal, M.A.H., Boie, W., and Denich, M., 2010, Future demand scenarios of Bangladesh power sector: Energy Policy, v. 38, p. 7416-7426.

Mondal, M.A.H., Mathur, J., and Denich, M., 2011, Impacts of $\mathrm{CO}_{2}$ emission constraints on technology selection and energy resources for power generation in Bangladesh: Energy Policy, v. 39, p. 2043-2050.

Mukherjee, A.K., Alam, M.M., Mazumdar, S.K., Haque, R., and Gowrisankaran, S., 1992, Physicochemical properties and petrographic characteristics of the Kapurdi lignite deposit, Barmer Basin, Rajasthan, India: International Journal of Coal Geology, v. 21, p. 31-44.

Muller, Mark, 2009, It's not only about coal mining-Coal-bed methane (CBM) and underground gasification (UCG) potential in Bangladesh: An independent technical review for Mines and Communities, accessed April 4, 2011, at http://www.accountabilityproject.org/downloads/Phulbari_CBM_Report_MRM.pdf.

Pareek, H.S., 1988, Petrographic characteristics of the solid fuels of India with particular reference to the coking coals: International Journal of Coal Geology, v. 10, p. 285-307.

Persits, F.M., Wandrey, C.J., Milici, R.C., and Manwar, Abdullah, comps., 1997, Digital geologic and geophysical data of Bangladesh: U.S. Geological Survey Open-File Report 97-470H, CD-ROM. (Also available at http://pubs.usgs.gov/of/1997/ofr-97-470/OF97-470H/.)

Petrobangla, 2011, Barakupuria Coal Mining Company Limited (BCMCL): BCMCL Web site, accessed April 5, 2011, at http://www.bcmcl.org.bd/.

Rage, J.-C., Bajpai, S., Thewissen, J.G.M., and Tiwari, B.N., 2003, Early Eocene snakes from Kutch, western India, with a review of the Palaeophiidae: Geodiversitas, v. 25, no. 4, p. 695-716.

Rahman, Q.M.A., Mohiuddin, M.Z., and Hassan, M., 1985, Geology of the Chandraghona-Kaptai area, Rangamati district, Bangladesh: Dhaka, Bangladesh, Records of the Geological Survey of Bangladesh, v. 3, pt. 3, 12 p.

SanFilipo, J.R., Wnuk, Christopher, Fariduddin, Mohammad, Ahmed, Mujeeb, Khan, S.A., Mentab-urRahman, Chandio, A.H., and Khan, R.A., 1992, Potential for the occurrence of thick lignite deposits in the Thar Desert and adjacent lower Indus Plain, Sindh Province, Pakistan: U.S. Geological Survey Open-File Report 92-576, 131 p. 
Sastry, M.V.A., Acharyya, S.K., Shah, S.C., Satsangi, P.P., Ghosh, S.C., Raha, P.K., Singh, Gopal, and Ghosh, R.N., comps., 1977, Stratigraphic lexicon of Gondwana formations of India: New Dehli, Geological Survey of India, Miscellaneous Publication No. 36, 170 p.

Sharma, K.D., Kumar, P., Gough, L.P., and SanFilipo, J.R., 2004, Rehabilitation of a lignite minedisturbed area in the Indian Desert: Land Degradation and Development, v. 15, p. 163-176.

Singh, M.P., and Singh, G.P., 1995, Petrological evolution of the Paleogene coal deposits of Jammu, Jammu and Kashmir, India: International Journal of Coal Geology, v. 27, p. 171-199.

Singh, P.K., Singh, M.P., and Singh, A.K., 2010, Petrochemical characterization and evolution of the Vastan lignite, Gujarat, India: International Journal of Coal Geology, v. 82, p. 1-16.

Tewalt, S.J., Kinney, S.A, and Merrill, M.D., 2008, GIS representation of coal-bearing areas in North, Central, and South America: U.S. Geological Survey Open-File Report 2008-1257. (Available online at http://pubs.usgs.gov/of/2008/1257/.)

Tewalt, S.J., Belkin, H.E., SanFilipo, J.R., Merrill, M.D., Palmer, C.A., Warwick, P.D., Karlsen, A.W., Finkelman, R.B., and Park, A.J., comps., 2010, Chemical analyses in the World Coal Quality Inventory, version 1: U.S. Geological Survey Open-File Report 2010-1196, 4 p. (Also available at http://pubs.usgs.gov/of/2010/1196/.)

U.S. Geological Survey, 2010, Divisions of geologic time; Major chronostratigraphic and geochronologic units: U.S. Geological Survey Fact Sheet 2010-3059, 2 p. (Also available at http://pubs.usgs.gov/fs/2010/3059.)

U.S. Geological Survey-Bangladesh Gas Assessment Team, 2001, U.S. Geological Survey-PetroBangla cooperative assessment of undiscovered natural gas resources of Bangladesh, in Wandrey, C.J., ed., Petroleum systems and related geologic studies in Region 8, south Asia: U.S. Geological Survey Bulletin 2208-A, 119 p. (Also available at http://pubs.usgs.gov/bul/b2208-a/b2208-a.pdf.)

U.S. Department of State, 2011, restricted U.S. Department of State Web site, accessed April 2010, at https://www.intelink.gov.

World Energy Council, 2010, World Energy Insight 2010: $21^{\text {st }}$ World Energy Congress report, accessed August 5, 2011, at http://www.worldenergy.org/documents/wec_combined.pdf. 